\title{
Synthesis, Characterization and Crystal Structure Determination of a New Indium (III) Complex: [In(5,5'-DiMeBiPy)Cl ${ }_{3}$ (DMSO)].2(DMSO)
}

\author{
SADIF A. SHIRVAN ${ }^{*}$, FEREYDOON KHAZALI and SARA HAYDARI DEZFULI
}

Department of Chemistry, Omidiyeh Branch, Islamic Azad University, Omidiyeh, Iran.

http://dx.doi.org/10.13005/ojc/300154

(Received: December 05, 2013; Accepted: January 07, 2014)

\begin{abstract}
[In(5,5'-DiMeBiPy)Cl ${ }_{3}$ (DMSO)].2(DMSO) complex (5,5'-DiMeBiPy is 5,5'-Dimethyl-2,2'bipyridine) was prepared from reaction of $\mathrm{InCl}_{3} \cdot 4 \mathrm{H}_{2} \mathrm{O}$ with $5,5^{\prime}$-DiMeBiPy in 1.1 molar ratio in DMSO. This compound has been characterized by IR, ${ }^{1} \mathrm{H}$ NMR, UV-Vis spectroscopy as well as $X$-ray crystallography. This compound crystallizes in the space group $P+$ of the triclinic system. The unit cell dimensions is: $a=8.6695(8) \AA, b=12.8456(14) \AA, c=13.0877(12) \AA$, $\alpha=78.258(8)^{\circ}, \beta=$ $85.270(8)^{\circ}, \gamma=74.932(8)^{\circ}$. According to X-ray structure determination, there are one molecules of the complex and two DMSO solvent molecules in the asymmetric unit. In this complex the geometry at the indium (III) center is octahedral, formed by two nitrogen atom of 5,5'-DiMeBiPy ligand, three chloride ions and one DMSO molecule in trans position to chloride ion.
\end{abstract}

Key words: Indium (III), 5,5'-Dimethyl-2,2'-bipyridine, DMSO, Crystal structure.

\section{INTRODUCTION}

Metal complexes containing 2,2'-bipyridine and phenanthroline ligands have gained importance due of their versatile roles as molecular scaffolding for supramolecular assemblies, and due to their applications in catalysis, electrochemistry biochemistry and ring-opening metathesis polymerization and biochemistry ${ }^{1-9}$.

On the other hand, the chemistry of indium compounds is of interest owing to their important application in catalysts, electronics and optics ${ }^{10-14}$. Several In(III) complexes, which have the formula $\left[\ln (\mathrm{N}-\mathrm{N}) \mathrm{Cl}_{3}(\right.$ Solv $\left.)\right],\left(\right.$ Solv = DMSO, DMF, $\mathrm{H}_{2} \mathrm{O}$,
$\mathrm{MeOH}$ and $\mathrm{EtOH})$, are known, such as $[\ln (\mathrm{BiPy})$ $\left.\mathrm{Cl}_{3}\left(\mathrm{H}_{2} \mathrm{O}\right)\right], \quad\left[\ln (\mathrm{BiPy}) \mathrm{Cl}_{3}(\mathrm{EtOH})\right]$, and [In(BiPy) $\left.\mathrm{Cl}_{3}\left(\mathrm{H}_{2} \mathrm{O}\right)\right] \cdot \mathrm{H}_{2} \mathrm{O},{ }^{15}$, [In(Phen) $\left.\mathrm{Cl}_{3}(\mathrm{DMSO})\right],{ }^{16}$, [In(4,4'$\left.\mathrm{DiMeBiPy}) \mathrm{Cl}_{3}(\mathrm{DMSO})\right],{ }^{17}$, [In(Phen) $\left.\mathrm{Cl}_{3}\left(\mathrm{H}_{2} \mathrm{O}\right)\right]$, $\left[\ln (\mathrm{Phen}) \mathrm{Cl}_{3}(\mathrm{EtOH})\right] \cdot \mathrm{EtOH},{ }^{18},\left[\ln \left(5,5^{\prime}-\mathrm{DiMeBiPy}\right)\right.$ $\left.\mathrm{Cl}_{3}(\mathrm{MeOH})\right]{ }^{19}$ and $\left[\mathrm{In}\left(4,4^{\prime}-\mathrm{DiTertBuBiPy}\right) \mathrm{Cl}_{3}(\mathrm{MeOH})\right]$. $\mathrm{CH}_{3} \mathrm{OH},{ }^{20}$ (where BiPy is 2,2'-bipyridine, Phen is 1,10-phenanthroline, 4,4'-DiMeBiPy is 4,4'dimethyl-2,2'-bipyridine, 5,5'-DiMeBiPy is 5,5'dimethyl-2,2'-bipyridine and 4,4'-DiTertBuBiPy is 4,4'-ditertiarybuthyl-2,2'-bipyridine).

We recently reported the coordination chemistry of In(III) with some substituted bipyridine ligands such as $\left[\ln \left(4,4^{\prime}-\mathrm{DiMeBiPy}\right) \mathrm{Cl}_{3}(\mathrm{MeOH})\right]$. 
$\mathrm{CH}_{3} \mathrm{OH},{ }^{21},\left[\ln \left(5,5^{\prime}-\right.\right.$ DiMeBiPy $\left.) \mathrm{Cl}_{3}(\mathrm{DMF})\right], \mathrm{H}_{2} \mathrm{O},{ }^{22}$ and $\left[\ln \left(6-\mathrm{MeBiPy} \mathrm{Cl}_{3}(\mathrm{DMSO})\right],{ }^{23}\right.$ (where 6-MeBiPy is 6-methyl-2,2'-bipyridine). Herein the synthesis, characterization and crystal structure of a new indium(III) complex containing 5,5'-Dimethyl-2,2'bipyridine ligand by the formula of [ $\ln (5,5$ '-DiMeBiPy) $\left.\mathrm{Cl}_{3}(\mathrm{DMSO})\right] .2(\mathrm{DMSO})$ have been reported.

\section{EXPERIMENTAL}

\section{Materials and instruments}

All chemicals were purchased from Merck and Aldrich. Infrared spectra $\left(4000-250 \mathrm{~cm}^{-1}\right)$ of solid samples were taken as $1 \%$ dispersion in $\mathrm{KBr}$ pellets using a Shimadzu-470 spectrometer. ${ }^{1} \mathrm{H}$ - and ${ }^{13} \mathrm{C}-\mathrm{NMR}$ spectra were recorded on a Bruker AC-300 $\mathrm{MHz}$ spectrometer operating in the quarter mode.

\section{Synthesis of [In(5,5'-DiMeBiPy)Cl ${ }_{3}$ (DMSO)]. 2DMSO}

5,5'-Dimethyl-2,2'-bipyridine (0.20g, 1.10 $\mathrm{mmol})$ in methanol $(5 \mathrm{ml})$ was added to a solution of $\mathrm{InCl}_{3} \cdot 4 \mathrm{H}_{2} \mathrm{O}(0.32 \mathrm{~g}, 1.10 \mathrm{mmol})$ in methanol $(5 \mathrm{ml})$ and the resulting colorless solution was stirred for $30 \mathrm{~min}$ at $40^{\circ} \mathrm{C}$. The suitable crystals for the $\mathrm{X}$-ray diffraction experiment were obtained by methanol diffusion to a colorless solution in DMSO. Suitable crystals were isolated after one week (yield $0.54 \mathrm{~g}$, 76.7\%). IR (CsI, cm ${ }^{-1}$ ): 3105m, 2993m, 2918, 1588m, $1514 \mathrm{~m}, 1478 \mathrm{~s}, 1396 \mathrm{~m}, 1330 \mathrm{~s}, 1313 \mathrm{~m}, 1256 \mathrm{~m}$, $1141 \mathrm{~m}, 1050 \mathrm{~s}, 986 \mathrm{~m}, 944 \mathrm{~s}, 868 \mathrm{~m}, 840 \mathrm{~s}, 715 \mathrm{~m}$, $645 \mathrm{w}, 525 \mathrm{~m}, 425 \mathrm{~m}, 394 \mathrm{~m}, 343 \mathrm{~m}, 310 \mathrm{~m}, 275 \mathrm{~m} .{ }^{1} \mathrm{H}$ NMR (DMSO-d $\left.\mathrm{d}_{6}, \mathrm{ppm}\right): 2.63(\mathrm{~s}, 3 \mathrm{H}), 8.40(\mathrm{~d}, 1 \mathrm{H})$, $8.83(\mathrm{~d}, 1 \mathrm{H})$ and $9.28(\mathrm{~s}, 1 \mathrm{H}) \cdot{ }^{13} \mathrm{C}$ NMR (DMSO-d $\mathrm{d}_{6}$, ppm): 19.3 (s), 126.1 (s), 141.3 (s), 144.9 (s), 147.6 (s) and 152.6 (s). UV-Vis: $\lambda_{\text {max }}$ (DMSO, nm), 295. Anal. Calcd for $\mathrm{C}_{18} \mathrm{H}_{30} \mathrm{Cl}_{3} \mathrm{InN}_{2} \mathrm{O}_{3} \mathrm{~S}_{3}(\%)$ : C, 33.79; $\mathrm{H}$, 4.69; N, 4.38. Found: C, 33.50; H, 4.65; N, 4.34.

\section{Crystal structure determination and refinement}

The X-ray diffraction measurements were made on a Bruker SMART 1000 CCD area detector diffractometer at $298 \mathrm{~K}$ (Mo-K $\alpha$ radiation, graphite monochromator, $\lambda=0.71073 \AA$ ). The structure was solved by SHELX-97 and SHELXTL and absorption correction was done using the SADABS and APEX2 programs ${ }^{24-25}$. Data collection, cell refinement and data reduction were done by APEX2, SAINT, SHELXTL, PLATON and MERCURY24-27.

\section{RESULTS AND DISCUSSION}

\section{Synthesis}

Compound [In(5,5'-DiMeBiPy) $\mathrm{Cl}_{3}$ (DMSO)]. 2(DMSO) was obtained from reaction of one equivalent of $\mathrm{InCl}_{3} \cdot 4 \mathrm{H}_{2} \mathrm{O}$ with one equivalent of 5,5'Dimethyl-2,2'-bipyridine in dimethylsulfoxide at room temperature, in $63 \%$ yield, Eq. (1):

$\mathrm{InCl}_{3}, 4 \mathrm{H}_{2} \mathrm{O}+5,55^{\prime}-\mathrm{DiM} \mathrm{BiPy} \frac{\mathrm{r.t}}{\mathrm{DMSO}}-\left[\mathrm{Ir}\left(5,5^{\prime}-\mathrm{DiMeBiPy}\right) \mathrm{Cl}_{3}(\mathrm{DMSO})\right] . \not(\mathrm{DMSO}) \quad$ Eq. (1)

Table 1: Crystallographic and structure refinements data of $\left[\ln \left(5,5^{\prime}-\mathrm{DiMeBiPy}^{\prime} \mathrm{Cl}_{3}\right.\right.$ (DMSO)].2(DMSO)

\begin{tabular}{|c|c|}
\hline & Complex \\
\hline Formula & $\mathrm{C}_{18} \mathrm{H}_{30} \mathrm{Cl}_{3} \mathrm{InN}_{2} \mathrm{O}_{3} \mathrm{~S}_{3}$ \\
\hline Formula weight & 639.82 \\
\hline Temperature /K & $298(2)$ \\
\hline Wavelength $\lambda / \AA$ & 0.71073 \\
\hline Crystal system & Triclinic \\
\hline Space Group & $\mathrm{P}^{+}$ \\
\hline Crystal size $/ \mathrm{mm}^{3}$ & $0.50 \times 0.40 \times 0.35$ \\
\hline$a / \AA$ & $8.6695(8)$ \\
\hline$b / \AA$ & $12.8456(14)$ \\
\hline$c / \AA$ & $13.0877(12)$ \\
\hline$\alpha /{ }^{\circ}$ & $78.258(8)$ \\
\hline$\beta /{ }^{\circ}$ & $85.270(8)$ \\
\hline$\gamma^{\circ}$ & $74.932(8)$ \\
\hline Volume / $\AA^{3}$ & $1377.3(2)$ \\
\hline Z & 2 \\
\hline Density (calc.) $/ \mathrm{g} \mathrm{cm}^{-1}$ & 1.543 \\
\hline$\theta$ ranges for data collection & $2.43-26.00$ \\
\hline$F(000)$ & 648 \\
\hline Absorption coefficient & 1.397 \\
\hline \multirow[t]{3}{*}{ Index ranges } & $-10 \leq h \leq 10$ \\
\hline & $-15 \leq k \leq 15$ \\
\hline & $-16 \leq I \leq 15$ \\
\hline Data collected & 10935 \\
\hline Unique data $\left(\mathrm{R}_{\text {inin }}\right)$ & $5378,(0.0963)$ \\
\hline Parameters, restrains & 272,0 \\
\hline Final $R_{1}, w R_{2}^{a}$ (Obs. data) & $0.0581,0.1513$ \\
\hline Final $R_{1}, w R_{2}^{a}$ (All data) & $0.0663,0.1566$ \\
\hline Goodness of fit on $\mathrm{F}^{2}(\mathrm{~S})$ & 1.057 \\
\hline Largest diff peak and hole /e $\AA^{3}$ & $1.479,-1.548$ \\
\hline
\end{tabular}

${ }^{\mathrm{a}} \mathrm{R}_{1}=\Sigma|| \mathrm{F}_{0}|-| \mathrm{F}_{\mathrm{c}} \| / \Sigma\left|\mathrm{F}_{0}\right|, W \mathrm{R}_{2}=\left[\Sigma\left(w\left(\mathrm{~F}_{0}^{2}-\mathrm{F}_{\mathrm{c}}{ }^{2}\right)^{2}\right) / \Sigma \mathrm{W}\left(\mathrm{F}_{0}^{2}\right)^{2}\right]^{1 / 2}$ 
Table 2. Selected bond distances $(\AA \AA)$ and bond angles ( ${ }^{\circ}$ ) of $\left[\ln \left(5,5^{\prime}-\mathrm{DiMeBiPy}\right) \mathrm{Cl}_{3}\right.$ (DMSO)].2(DMSO)

\begin{tabular}{llll}
\hline \multicolumn{4}{c}{ Bond distances } \\
\hline In1-N1 & $2.293(4)$ & $\ln 1-\mathrm{Cl} 2$ & $2.4354(14)$ \\
In1-N2 & $2.285(4)$ & $\ln 1-\mathrm{Cl} 3$ & $2.4600(15)$ \\
In1-Cl1 & $2.4190(16)$ & $\ln 1-\mathrm{O} 1$ & $2.250(4)$ \\
\multicolumn{4}{c}{ Bond angles } \\
Cl1-In1-Cl2 & $99.61(6)$ & $\mathrm{N} 1-\ln 1-\mathrm{Cl} 1$ & $164.85(12)$ \\
Cl1-In1-Cl3 & $98.33(6)$ & $\mathrm{N} 1-\ln 1-\mathrm{Cl} 2$ & $93.52(11)$ \\
Cl2-In1-Cl3 & $97.07(6)$ & $\mathrm{N} 1-\ln 1-\mathrm{Cl} 3$ & $87.43(11)$ \\
O1-In1-Cl1 & $90.23(11)$ & $\mathrm{N} 1-\ln 1-\mathrm{N} 2$ & $71.90(15)$ \\
O1-In1-Cl2 & $87.81(11)$ & $\mathrm{N} 2-\ln 1-\mathrm{Cl} 1$ & $93.85(12)$ \\
O1-In1-Cl3 & $169.26(10)$ & $\mathrm{N} 2-\ln 1-\mathrm{Cl} 2$ & $162.74(11)$ \\
O1-In1-N1 & $82.71(14)$ & $\mathrm{N} 2-\ln 1-\mathrm{Cl} 3$ & $91.58(11)$ \\
O1-In1-N2 & $81.33(14)$ & & \\
\hline
\end{tabular}

Table 3: Hydrogen bond geometry of [In(5,5'-DiMeBiPy) $\mathrm{Cl}_{3}$ (DMSO)].2(DMSO) in crystal packing $\left(\AA{ }^{\circ}{ }^{\circ}\right)$

\begin{tabular}{|c|c|c|c|c|c|}
\hline D-H...A & D-H & H...A & D...A & D-H...A & Symmetry code \\
\hline $\mathrm{C} 1-\mathrm{H} 1 \ldots \mathrm{Cl} 2$ & 0.93 & 2.780 & $3.437(5)$ & 129 & - \\
\hline $\mathrm{C} 12-\mathrm{H} 12 \ldots \mathrm{Cl} 1$ & $1.0(2)$ & 2.780 & $3.3438(7)$ & 128 & - \\
\hline $\mathrm{C} 14-\mathrm{H} 14 \mathrm{C} \cdots \mathrm{Cl} 2$ & $1.0(2)$ & 2.750 & $3.565(10)$ & 143 & $2-x, 1-y, 1-z$ \\
\hline $\mathrm{C} 13-\mathrm{H} 13 \mathrm{~B} \cdots \mathrm{O} 2$ & $0.96(1)$ & 2.625 & $3.439(8)$ & 142 & $x, 1+y, z$ \\
\hline
\end{tabular}

The suitable crystal for X-ray diffraction experiment was obtained by slow evaporation of DMSO in room temperature after three weeks. Synthesized complex was thoroughly characterized by elemental analysis, IR and ${ }^{1} \mathrm{H}$-NMR spectroscopy.
Elemental analysis data $(\mathrm{C}, \mathrm{H}, \mathrm{N})$ support the general composition of the complex and the structures have been established by single-crystal X-ray diffraction study.
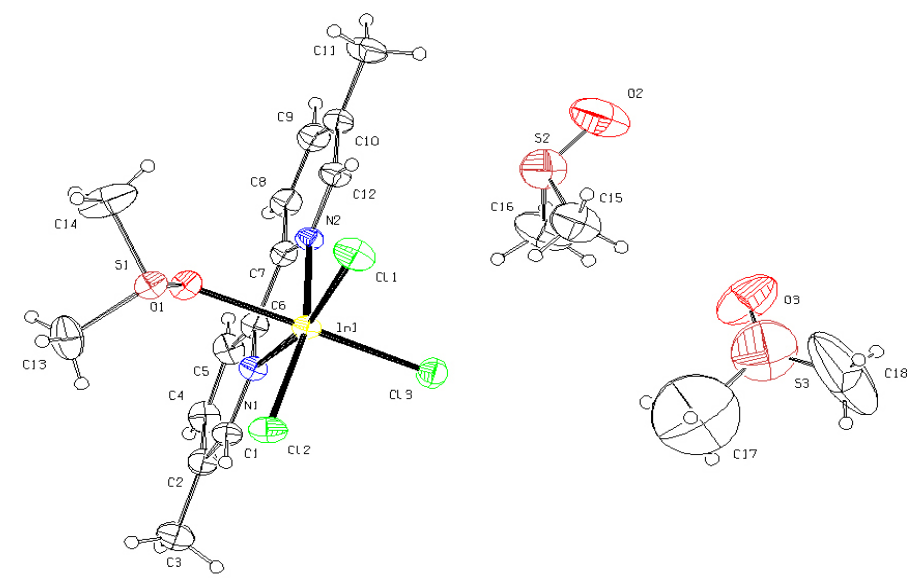

Fig. 1: The labeled diagram of [In(5,5'-DiMeBiPy)Cl ${ }_{3}$ (DMSO)]. 2(DMSO). Thermal ellipsoids are at $50 \%$ probability level 
NMR, IR and Uv-vis investigation

Compound [In( $5,5^{\prime}$ - DiMeBiPy) $\mathrm{Cl}_{3}$ (DMSO)].2(DMSO) is stable in air and can be used directly for routine analyses. The vibrational band present at $3105 \mathrm{~cm}^{-1}$ is assigned to $v\left(\mathrm{C}-\mathrm{H}_{\text {cycle }}\right)$ and two vibrational bands present at 2993 and 2918 $\mathrm{cm}^{-1}$ are assigned to $\mathrm{v}\left(\mathrm{C}-\mathrm{H}_{\mathrm{Me}}\right)$. The several bands in the range $1588-1313 \mathrm{~cm}^{-1}$ are assigned to $v(\mathrm{C}=\mathrm{N})$ and $v(\mathrm{C}=\mathrm{C})$ vibrations. Medium to strong vibration bands in the range $986-525 \mathrm{~cm}^{-1}$ are assigned to deformation vibrations $\delta(\mathrm{C}=\mathrm{C}=\mathrm{N})$ and $\delta(\mathrm{C}=\mathrm{C}=\mathrm{C})$ in the pyridine rings ${ }^{28-32}$. In addition, two strong signals at 1050 and $944 \mathrm{~cm}^{-1}$ has been assigned to $v(S=0)$ for free and coordinated DMSO, respectively ${ }^{33-35}$. Far infrared spectra for title complex were recorded between 425 and $264 \mathrm{~cm}^{-1}$. In-O stretching vibration is seen at $425 \mathrm{~cm}^{-1}$. The In- $\mathrm{N}$ stretching vibration is seen at 394 and $343 \mathrm{~cm}^{-1}$ and $\mathrm{In}-\mathrm{Cl}$ stretching vibration is seen at 310 and $275 \mathrm{~cm}^{-133-35}$.

The UV-Vis spectrum of the DMSO solution of 1 have band at $295 \mathrm{~nm}$ which can be assigned to the $\pi \rightarrow \pi^{\star}$ transition ${ }^{31}$. NMR spectroscopy studies were conducted to characterize the chemical structure of

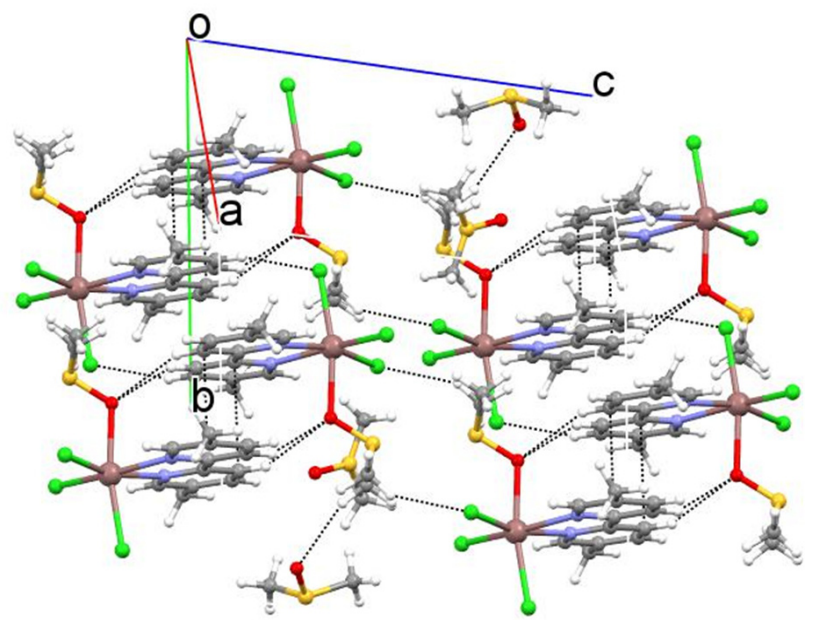

Fig. 2: Crystal packing diagram of [In(5,5'-DiMeBiPy)Cl $\left.\mathrm{Cl}_{3}(\mathrm{DMSO})\right] .2(\mathrm{DMSO})$ showing the C-H...CI and $\mathrm{C}-\mathrm{H}$... O hydrogen bonds and $\pi$... $\pi$ stacking interactions between adjacent molecules

title complex. A comparison between ${ }^{1} \mathrm{H}$ and ${ }^{13} \mathrm{CNMR}$ spectra of title complex and 5,5'-dmbpy ligand, clearly indicated the coordination of ligand to $\ln (\mathrm{III})$. It can be deduced from NMR data that in the solution, the 5,5'dmbpy ligand have a symmetrical environment. As expected, the ${ }^{1} \mathrm{H}$ NMR spectrum exhibited a singlet at $2.63 \mathrm{ppm}$ for methyl, a doublet at $8.40 \mathrm{ppm}$, a doublet at 8.83 ppm and a singlet at 9.28 for the aromatic rings. The ${ }^{13} \mathrm{C}$ NMR spectrum showed a singlet at $19.3 \mathrm{ppm}$, for $\mathrm{CH}_{3}$ groups and five singlets at 126.1 to $152.6 \mathrm{ppm}$ for the aromatic rings.

\section{Description of the molecular structure of [ $\ln \left(5,5^{\prime}-\right.$ DiMeBiPy) $\mathrm{Cl}_{3}$ (DMSO)]. 2(DMSO)}

The colorless prismatic crystals of [In(5,5'DiMeBiPy) $\mathrm{Cl}_{3}$ (DMSO)].2(DMSO) were grown by slow evaporation of DMSO solution during three weeks. Table 1 shows details of collected data and refinement of the X-ray crystal structure determination for this compound. Selected bond lengths and bond angles are presented in Table 2 . The crystal structure of this complex consists of 3 chloride ion, one chelating 5,5'-Dimethyl-2,2'-bipyridine and one DMSO. Two DMSO molecules are in the unit cell as solvent. ORTEP view with numbering scheme and packing diagram is shown in Figure 1. The complex have distorted octahedral geometry. In this complex indium has pseudo-octahedral coordination with facarrangement of chlorine atoms. In-Cl bond lengths differ strongly around indium center. The bond lengths $\ln 1-\mathrm{Cl} 3$ (chlorine atom is trans to oxygen) is longer than distances $\ln 1-\mathrm{Cl} 1$ and $\mathrm{In}-\mathrm{Cl} 2$ [C11 and $\mathrm{Cl} 2$ atoms are trans to nitrogen atoms].

As it is shown in Figure 2, the 5,5'-Dimethyl2,2'-bipyridine ligands form $\sigma$ bonding stacks in which each bipy ligand lies between two bipy ligands of adjacent indium complexes. The centroid to centroid 
distance between adjacent aromatic rings are 3.605 and $3.937 \AA$. Weak $\mathrm{C}-\mathrm{H}$...Cl and $\mathrm{C}-\mathrm{H}$...O hydrogen bonds are linked adjacent molecules in another direction to generate a 3D packing, Table 3.

\section{ACKNOWLEDGMENTS}

We would like to thank the Islamic Azad University, Omidieh Branch for financial support.

\section{REFERENCES}

1. Chow C. S., Bogdan F. M., Chem. Rev., 97: 1489 (1997).

2. Sammes P. G., Yahioglu G. Chem. Soc. Rev., 23: 327 (1994).

3. Balzani V., Juris A., Venturi M., Campagna S., Serroni S., Chem. Rev., 96: 759 (1996).

4. Calderazzo F., Pampaloni G., Passarelli V., Inorg. Chim. Acta, 330: 136 (2002).

5. Steed J. W., Atwood J. L., Supramolecular Chemistry, Wiley, Chichester (2000).

6. Larsson K., Öhrström L., Inorg. Chim. Acta, 357: 657 (2004).

7. BinnemansK., Lenaerts P., Driesen K., Görller-Walrand C., J. Mater. Chem., 14: 191 (2004).

8. Lenaerts P., Storms A., Mullens J., D’Haen J. Görller-Walrand C., Binnemans K., Driesen K., Chem. Mater., 17: 5194 (2005).

9. V. Gomathi, R. Selvameena, R. Subbalakshmi and G. Valarmathy, Orient J. Chem., 29(2): 533-538 (2013).

10. Frost C. G., Hartley J. P., Mini-Reviews in Organic Chemistry, 1 (2004).

11. Allen C. L. Burel C., Williams J. M. J. Tetrahedron Let., 51: 2724 (2010).

12. Li C., Zhang D., Han S., Liu X., Tang T., Lei B., Liu Z., Zhou C., Ann. N.Y. Acad. Sci., 1006: 104 (2003).

13. Cansizoglu M. F., Engelken R., Seo H. W., Karabacak T., ACS Nano, 4, 733 (2010).

14. A. Saxena and R. Saxena, Orient J. Chem., 29(2): 589-595 (2013).

15. Malyarick M. A., Petrosyants S. P., llyukhin A. B., Polyhedron, 11: 1067 (1992).

16. Nan D., Naidong W., Zhenchao D., Shengzhi H., Jiegou Huaxue, 6: 145 (1987).

17. Ahmadi R., Kalateh K., Abedi A., Amani V., Khavasi H. R., Acta Crystallogr., E64, m1306 (2008).

18. Ilyukhin A. B., Malyarik M. A., Kristallografiya, 39: 439 (1994).

19. Kalateh K., Ahmadi R., Ebadi A., Amani V., Khavasi H. R., Acta Crystallogr., E64, m1353
(2008).

20. Abedi A., Safari A.R., Amani V., Z.Kristallogr. New Cryst. Struct., 227: 196 (2012).

21. Shirvan S.A., Haydari Dezfuli S., Acta Crystallogr., E68: m1189 (2012).

22. Shirvan S. A., Haydari Dezfuli S., Khazali F., Aghajeri M., Borsalani A., Acta Crystallogr., E68, m1448 (2012).

23. Shirvan S. A., Haydari Dezfuli S., Golabi E., Gholamzadeh M. A., Acta Crystallogr., E68: m1327 (2012).

24. Sheldrick G. M., SADABS. Bruker AXS, Madison, Wisconsin, USA (1998).

25. Bruker, APEX2 software package,version 2.0-1, Bruker AXS Inc. Madison, Wisconsin, USA (2005).

26. Sheldrick G. M., SHELXTL v. 5.1, Structure Determination Software Suite, Bruker AXS, Madison, Wisconsin, USA (1998).

27. Mercury, Copyright Cambridge Crystallographic Data Center, 12 Union Road, Cambridge, CB2 1EZ, UK (2006).

28. Amani V., Safari N., Khavasi H. R., Polyhedron, 26: 4257 (2007).

29. Amani V., Safari N., Khavasi H. R., Mirzaei, P., Polyhedron, 26: 4908 (2007).

30. Amani V., Safari N., Khavasi H. R., Akkurt, M., Polyhedron, 28: 3026 (2009).

31. Alizadeh R., Amani V., Struct. Chem., 22: 1153 (2011).

32. Alizadeh R., Amani V., Farshady A. A., Khavasi H.R. J. Coord. Chem., 63: 2122 (2010).

33. Nakamoto K., Infrared and Raman Spectra of Inorganic and Coordination Compound Part B: Application in Coordination, Organometallic and Bioinorganic Chemistry, John Wiley and Sons Inc., New York (2009).

32. Abedi A., Safari N., Amani V., Khavasi H. R., J. Coord. Chem., 65: 325 (2012).

33. Abedi A., Amani V., Safari N., Main Group Chem., 11: 223 (2012). 